\title{
Co-culture of Human Stem Cell Derived Neurons and Oligodendrocyte Progenitor Cells
}

Stephanie Dooves ${ }^{1, \#}$, Aishwarya G. Nadadhur², \#, Lisa Gasparotto ${ }^{1}$ and Vivi M. Heine ${ }^{1,3, *}$

${ }^{1}$ Pediatric Neurology, Emma Children's Hospital, Amsterdam UMC, Amsterdam, Neuroscience, Vrije Universiteit Amsterdam, The Netherlands; ${ }^{2 D e p a r t m e n t}$ of Functional Genomics, Center for Neurogenomics and Cognitive Research, Amsterdam Neuroscience, Vrije Universiteit Amsterdam, The Netherlands; ${ }^{3}$ Department of Complex Trait Genetics, Center for Neurogenomics and Cognitive Research, Amsterdam Neuroscience, Vrije Universiteit Amsterdam, The Netherlands

*For correspondence: vm.heine@amsterdamumc.nl

\#Contributed equally to this work

[Abstract] Crosstalk between neurons and oligodendrocytes is important for proper brain functioning. Multiple co-culture methods have been developed to study oligodendrocyte maturation, myelination or the effect of oligodendrocytes on neurons. However, most of these methods contain cells derived from animal models. In the current protocol, we co-culture human neurons with human oligodendrocytes. Neurons and oligodendrocyte precursor cells (OPCs) were differentiated separately from pluripotent stem cells according to previously published protocols. To study neuron-glia cross-talk, neurons and OPCs were plated in co-culture mode in optimized conditions for additional 28 days, and prepared for OPC maturation and neuronal morphology analysis. To our knowledge, this is one of the first neuronOPC protocols containing all human cells. Specific neuronal abnormalities not observed in monocultures of Tuberous Sclerosis Complex (TSC) neurons, became apparent when TSC neurons were cocultured with TSC OPCs. These results show that this co-culture system can be used to study human neuron-OPC interactive mechanisms involved in health and disease.

Keywords: Human iPSC, Neuron, Oligodendrocyte, Co-culture, Myelin, Neuron-glia interaction

[Background] The human brain consists of an immense complex organization of cells that we are only recently starting to identify, and that cannot be studied in animal models. The human brain also contains a high white matter content, which is suggested to account for higher brain functions, such as social and cognitive learning (Maldonado and Angulo, 2015; Almeida and Lyons, 2016; Kougioumtzidou et al., 2017). Single cell expression studies in animals indicate that oligodendrocytes form heterogeneous populations of cells (Marques et al., 2016). This supports the notion that oligodendrocytes fulfill more complex functions than solely isolating axons. As the human comprises of higher diversity of neurons compared to rodent brain, and considering the role of white matter in complex functions in learning and cognition, we could expect an even more complex diversity of oligodendrocyte lineage cells in the human brain. Therefore, we need to identify oligodendrocyte-neuron crosstalk in the human brain. Next to the classic white matter disorders, such as multiple sclerosis and the leukodystrophies (van der Knaap and Bugiani, 2017), white matter abnormalities are consistently been found in psychiatric disorders (Haroutunian et al., 2014). Increasing evidence shows that crosstalk between neurons and 
oligodendrocytes is important for proper neural network functioning (Bergles et al., 2000; Velez-Fort et al., 2010; Maldonado and Angulo, 2015) and myelin formation (Almeida and Lyons, 2016; Kougioumtzidou et al., 2017). Therefore, to study the involvement of neuron-oligodendrocyte interactions in the normal and diseased brains, we are in need of human-based model systems. As current assays mostly involve non-human cells (Cui et al., 2010; Hill et al., 2014; Clark et al., 2017; Pang et al., 2018; Treichel and Hines, 2018), we developed human induced pluripotent stem cell (iPSC)-based co-culture models to study crosstalk between human neurons and human oligodendrocyte progenitor cells (OPCs). The presented co-culture method was used to study neuron-OPC interactions in Tuberous Sclerosis Complex (TSC) (Nadadhur et al., 2019), a genetic multisystem disorder that shows both grey and white matter abnormalities in the brain. Although some neuronal abnormalities were present in mono-cultures of TSC neurons, in the presence of OPCs increased axonal density and hypertrophy became apparent (Nadadhur et al., 2019). This suggests that specific neuronal phenotypes can only be studied when oligodendrocytes are present. Vice versa oligodendrocyte maturation is highly dependent on neuronal signaling. Therefore these culture systems can be applied to study multiple processes in health and disease in which complex neuron-oligodendrocyte interactions are involved, and provide prospects for the development of drug screening platforms for all-human cells, e.g., patient iPSCs. To conclude, this novel human neuron-OPC co-culture model can be used to study neuron-OPC crosstalk in health and disease.

\section{Materials and Reagents}

1. 12-well plate (VWR, catalog number: 665180)

2. $10 \mu$ filter tips (Thermo Fisher, catalog number: 11977714)

3. $100 \mu$ filter tips (Thermo Fisher, catalog number: 11953466)

4. $1000 \mu$ filter tips (Thermo Fisher, catalog number: 11973466)

5. 6-well plate (VWR, catalog number: 734-2323)

6. $18 \mathrm{~mm}$ coverslips (VWR, catalog number: 631-0153)

7. $5 \mathrm{ml}$ pipette (VWR, catalog number: 606180)

8. $10 \mathrm{ml}$ pipette (VWR, catalog number: 607180)

9. $15 \mathrm{ml}$ tube (VWR, catalog number: 525-0400)

10. Microscope slide (VWR, catalog number: 631-0108)

11. Syringe needle (BD Biosciences, catalog number: 300400 )

12. 4',6-Diamidino-2-Phenylindole (DAPI) (Sigma-Aldrich, catalog number: D9542-5MG)

13. Accutase (Merck-Millipore, catalog number: sf006)

14. Anti-MAP2 antibody (Abcam, catalog number: AB5392)

15. Anti-MBP antibody (Covance, catalog number: SMI-99P)

16. Anti-Olig2 antibody (Merck-Millipore, catalog number: AB9610)

17. Anti-SMI312 antibody (Eurogentec, catalog number: SMI-312P-050)

18. Arabinosylcytosine (AraC) (Merck-Millipore, catalog number: 251010) 
19. $\beta$-mercaptoethanol (Thermo Fisher Scientific, catalog number: 21985023)

20. B27 with vitamin A (Thermo Fisher Scientific, catalog number: 17504-044)

21. B27 without vitamin $A$ (Thermo Fisher Scientific, catalog number: 12587-010)

22. Basic fibroblast growth factor (bFGF) (Peprotech, catalog number: 100-18B-50ug)

23. Brain-derived neurotrophic factor (BDNF) (Peprotech, catalog number: 450-02)

24. Biotin (Sigma-Aldrich, catalog number: B4501-100MG)

25. Bovine Serum albumin (BSA) (Sigma-Aldrich, catalog number: A9418)

26. Cyclic adenosine monophosphate (cAMP) (Sigma, catalog number: D0260-5MG)

27. Defined Trypsin Inhibitor (DTI) (Thermo Fisher Scientific, catalog number: R007100)

28. DMEM/F12 with Glutamax (Life Technologies, catalog number: 21331-020)

29. DMEM/F12 without L-glutamine (Life Technologies, catalog number: 21331-046)

30. Dimethylsulfoxide (DMSO) (Sigma-Aldrich, catalog number: D2650)

31. Dorsomorphin (Tocris Bioscience, catalog number: 3093/10)

32. Epidermal growth factor (EGF) (Peprotech, catalog number: AF-100-15-500ug)

33. Ethylenediaminetetraacetic acid (EDTA) (Invitrogen, catalog number: 15575-038)

34. Fetal Bovine Serum (FBS) (ThermoFisher Scientific, catalog number: 16140063)

35. Fluoromount $\mathrm{G}$ (Southern Biotech, catalog number: 0100-01)

36. Glial-cell derived neurotrophic factor (GDNF) (Peprotech, catalog number: 450-10)

37. Geltrex (Life Technologies, catalog number: A1413302)

38. Glutamax (Thermo Fisher Scientific, catalog number: 35050-038)

39. Goat anti-rat/mouse/rabbit/chicken/guinea pig Alexa Fluor antibodies (Life Technologies)

40. Heparin (Sigma-Aldrich, catalog number: H3393-50KU)

41. HEPES (Thermo Fisher Scientific, catalog number: 15630-056)

42. Human Sonic Hedgehog (hSHH) (Peprotech, catalog number: 100-45-500ughSHH)

43. Insulin-like growth factor 1 (IGF1) (Peprotech, catalog number: 100-11-100ug)

44. Insulin (Sigma-Aldrich, catalog number: 19278)

45. $\mathrm{KCl}$ (Sigma-Aldrich, catalog number: P5405-250gr)

46. $\mathrm{KH}_{2} \mathrm{PO}_{4}$ (Sigma-Aldrich, catalog number: P5379)

47. L-glutamine (Thermo Fisher Scientific, catalog number: 25030-024)

48. Mouse laminin (mLaminin) (Sigma-Aldrich, catalog number: L2020-1mg)

49. N2 supplement (Thermo Fisher Scientific, catalog number: 17502-048)

50. $\mathrm{Na}_{2} \mathrm{HPO}_{4}$ (Sigma-Aldrich, catalog number: S7907-500gr)

51. $\mathrm{NaCl}(\mathrm{VWR}$, catalog number: $\mathrm{S} 9888-1 \mathrm{Kg})$

52. Neurobasal medium (Thermo Fisher Scientific, catalog number: 21103-049)

53. Neurotrophin 3 (NT3) (Peprotech, catalog number: 450-03-100ug)

54. Noggin (Peprotech, catalog number: 120-10C)

55. Non-essential amino acids (NEAA) (Thermo Fisher Scientific, catalog number: 11140-035)

56. Normal goat serum (NGS) (Life Technologies, catalog number: 16210-064)

57. Penicillin/streptomycin (Pen/Strep) (Sigma-Aldrich, catalog number: P0781) 
58. Paraformaldehyde (PFA) 16\% (Electron Microscopy Sciences, catalog number: 15710-S)

59. Poly-L-ornithine (PLO) (Sigma-Aldrich, catalog number: P3655-100mg)

60. Rock Inhibitor (RI) (Y27632; Selleckchem, catalog number: S1049)

61. Retinoic Acid (RA) (Sigma-Aldrich, catalog number: R2625-100MG)

62. SB431542 (Selleckchem, catalog number: S1067)

63. Triiodothyronine (T3) (Sigma-Aldrich, catalog number: T6397-100MG)

64. TeSRE8 (Stem Cell Technologies, catalog number: 5940)

65. Triton X-100 (Sigma-Aldrich, catalog number: T8787-100ml)

66. TryplE (Life Technologies, catalog number: 12563-029)

67. Valproic acid (VPA) (Sigma-Aldrich, catalog number: P4543-10G)

68. Vitamin C/Ascorbic Acid (Sigma-Aldrich, catalog number: A4544-25G)

69. N1 supplement (Sigma-Aldrich, catalog number: N6530-5ML)

70. Neuroglia co-culture medium (see Recipes)

71. Neural Maintenance Medium (NMM) with Vitamin A (see Recipes)

72. Neural Maintenance Medium (NMM) without Vitamin A (see Recipes)

73. N2 medium (see Recipes)

74. NB medium (see Recipes)

75. Blocking Buffer (see Recipes)

76. PBS (see Recipes)

77. PLO/mLaminin coating (see Recipes)

78. Geltrex coating (see Recipes)

\section{Equipment}

1. Pipette controller (BD Biosciences, model number: Falcon Express)

2. Incubator (Binder, model number: $9140-0044 ; 5 \% \mathrm{CO}_{2}, 20 \% \mathrm{O}_{2}$ )

3. Tabletop Centrifuge (Eppendorf, model number: centrifuge 5810)

4. $-80^{\circ} \mathrm{C}$ freezer (Thermo Fisher Scientific; model number ULT1786-6-V49)

5. Bright field microscope (Zeiss, model number: Axiovert 40C.)

6. Fluorescent microscope (Leica Microsystems, model number: Leica DM6000B)

\section{Software}

1. Columbus 2.5 online software (Perkin Elmer)

2. Leica Application Suite Advanced Fluorescence (Leica)

\section{Procedure}

A. Neuronal differentiation 
Neurons are differentiated according to previously published protocols (Shi et al., 2012; Nadadhur et al., 2017), shortly:

1. hiPSCs are passaged onto Geltrex-coated 12-well plates in $1 \mathrm{ml}$ TesRE8 medium with $10 \mu \mathrm{M}$ RI per well.

2. Refresh all medium every day.

3. After 2 days (or when cells are $100 \%$ confluent), add $1 \mathrm{ml}$ neural maintenance medium (NMM) with vitamin A + $1 \mu \mathrm{M}$ Dorsomorphin + $10 \mu \mathrm{M}$ SB431542.

4. Refresh all medium every day until Day 12 .

Note: Between Days 8 and 12 a uniform neuroepithelial sheet should appear (see Figure 1).

5. Prepare a PLO/mLaminin coated 6-well plate as described in the Recipes.

6. Collect neuroepithelial rosette cells (NES cells) by manually cutting them (see description in note) and plate them in the 6-well plate.

Note: Prepare fresh pre-warmed NMM with vitamin A + $1 \mu M$ Dorsomorphin + $10 \mu M$ SB431542 $+10 \mu \mathrm{M}$ RI. Remove the medium from the 12-well plate, wash the wells with PBS once and add $1 \mathrm{ml}$ of the freshly prepared medium. Sterilize the microscope area with 70\% Ethanol and cut the rosettes using a $10 \mu \mathrm{l}$ tip to mark their borders and to lift them up. Collect the floating rosettes with a $5 \mathrm{ml}$ pipette and move them to the PLO/mLaminin coated 6-well plate with NMM with vitamin A + $1 \mu$ M Dorsomorphin $+10 \mu M$ SB431542 + $10 \mu M$ RI. All rosettes from 1 well of a 12well plate are plated in 1 well of a 6-well plate.

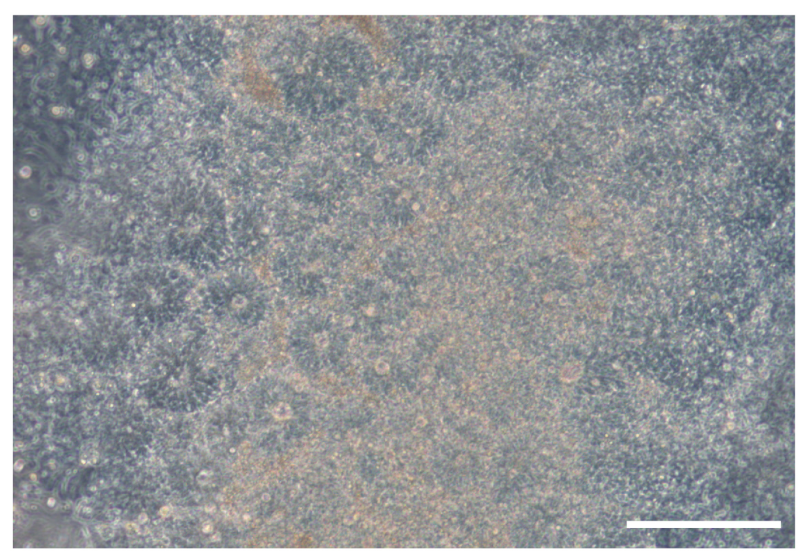

Figure 1. Brightfield picture showing neural rosette structures that form between Days 8 and 12. Scale bar $=200 \mu \mathrm{m}$.

7. On Day 13 , change the medium to $2 \mathrm{ml}$ pre-warmed $\mathrm{NMM}$ with vitamin $\mathrm{A}+20 \mathrm{ng} / \mathrm{ml} \mathrm{bFGF}+20$ $\mathrm{ng} / \mathrm{ml}$ EGF.

8. Every day remove $1 \mathrm{ml}$ of medium and add $1 \mathrm{ml}$ pre-warmed $\mathrm{NMM}$ with vitamin $A+40 \mathrm{ng} / \mathrm{ml}$ $\mathrm{bFGF}+40 \mathrm{ng} / \mathrm{ml}$ EGF. When confluent, passage the cells with TrypLE in a 1:2 or 1:3 ratio as described in the note below.

Notes:

a. Cells can be kept in NES cell stage for 1-4 passages. 
b. Growth factor concentration is double when only half the medium is changed: together with the medium left in the well the concentration will be similar to the concentration in Step A7.

c. TrypLE passage: Remove all medium from the well and add $300 \mu \mathrm{l}$ pre-warmed TrypLE. Swirl it around the well and incubate for $2 \mathrm{~min}$ at room temperature (RT). Add $600 \mu \mathrm{l}$ of prewarmed DTI or medium to stop the reaction and collect the cells into a tube containing $5 \mathrm{ml}$ NMM. Spin down at $300 \times \mathrm{g}$ for $5 \mathrm{~min}$ at RT and re-suspend the pellet in desired medium.

9. To start the neuronal induction, plate the NES cells after a TrypLE passage in a PLO/mLaminincoated 12-well plate in pre-warmed $1 \mathrm{ml} \mathrm{NMM}+20 \mathrm{ng} / \mathrm{ml} \mathrm{bFGF}+20 \mathrm{ng} / \mathrm{ml} \mathrm{EGF}$ per well.

10. When cells reach $80 \%-90 \%$ confluence, switch half of the medium (500 $\mu / /$ well) to pre-warmed $\mathrm{N} 2$ medium $+800 \mathrm{ng} / \mathrm{ml} \mathrm{hSHH}$.

Note: This is considered Day 1 of the differentiation protocol.

11. Until Day 4, refresh half of the medium ( $500 \mu \mathrm{l} /$ well) daily with pre-warmed $\mathrm{N} 2$ medium +800 $\mathrm{ng} / \mathrm{ml} \mathrm{hSHH}$.

12. On Day 5 , switch half of the medium ( $500 \mu \mathrm{l} /$ well) to pre-warmed NB medium $+40 \mu \mathrm{M}$ VPA.

13. Until Day 7 , refresh half of the medium $(500 \mu \mathrm{l} /$ well) daily with pre-warmed NB medium $+40 \mu \mathrm{M}$ VPA.

14. Prepare PLO/mLaminin-coated 12-well plates before Day 8 as described in the Recipes.

15. On Day 8, passage the neural progenitors with accutase $1: 2$ or 1:3 to a new well (see note for explanation). Plate cells in pre-warmed $1.5 \mathrm{ml} \mathrm{NB}$ medium $+20 \mathrm{ng} / \mathrm{ml} \mathrm{BDNF}+10 \mathrm{ng} / \mathrm{ml}$ GDNF $+10 \mathrm{ng} / \mathrm{ml} \mathrm{IGF} 1+1 \mu \mathrm{M}$ cAMP.

Accutase treatment: Remove all medium, add $300 \mu \mathrm{l}$ of accutase per well of a 12-well plate and return the plate to the incubator for 5-7 min. By gently tapping the plate, the cells will visibly come off. At this point, collect the cells in a tube, add $5 \mathrm{ml}$ fresh pre-warmed medium, spin at $300 \times \mathrm{g}$ for $5 \mathrm{~min}$ at RT and re-suspend the pellet in the desired medium. Resuspend carefully; do not break clumps into single cells.

16. Until Day 18 refresh medium three times a week by removing $1 \mathrm{ml}$ of medium and adding $1 \mathrm{ml}$ of pre-warmed NB medium $+30 \mathrm{ng} / \mathrm{ml} \mathrm{BDNF}+15 \mathrm{ng} / \mathrm{ml} \mathrm{GDNF}+15 \mathrm{ng} / \mathrm{ml} \mathrm{IGF} 1+1.5 \mu$ M cAMP.

17. On Day 12, prepare a 12-well sandwich plate as described in the note, Figure 2 and Video 1. Coat the plate with Geltrex as described in the Recipes. Plate 25,000 primary rat astrocytes in each well containing pre-warmed DMEM/F12 medium with Glutamax $+10 \%$ FBS + 1x NEAA + 1x Pen/Strep.

Note: Sandwich plate preparation: Take a 12-well plate and heat up a sterile syringe needle in flame. Punch in 4 corners of each well to make uniform small bumps in the plastic bottom of the well. These bumps will help suspend a coverslip on them, separated by a small distance from the cells in the bottom of the well. See Figure 2 and Video 1. 


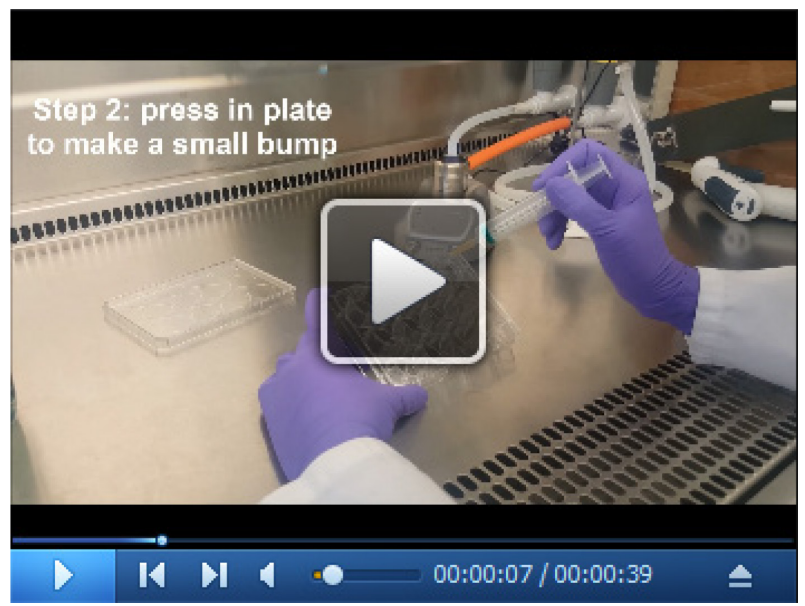

Video 1. Sandwich plate

18. Before Day 18, prepare the desired amount of 12-well plates containing $18 \mathrm{~mm}$ diameter coverslips and coat with PLO/laminin as described in the Recipes.

Note: Coverslips can be stored by sealing the plate tightly with parafilm for maximum 1 week at $4{ }^{\circ} \mathrm{C}$.

19. On Day 18, make a single-cell suspension of the neurons using accutase as described in the note. Plate 1.5 million cells per 12-well plate on the pre-coated PLO/mLaminin coverslips in prewarmed $1 \mathrm{ml} \mathrm{NB}$ medium $+20 \mathrm{ng} / \mathrm{ml} \mathrm{BDNF}+10 \mathrm{ng} / \mathrm{ml} \mathrm{GDNF}+10 \mathrm{ng} / \mathrm{ml} \mathrm{IGF} 1+1 \mu \mathrm{M}$ cAMP. Note: Remove all medium, add $300 \mu \mathrm{l}$ of accutase per well of a 12-well plate and return the plate to the incubator for 10-15 min. By gently tapping the plate, the cells will visibly come off. Dissociate the cells in the accutase using a $1000 \mu$ pipette very slowly and pipet into a $15 \mathrm{ml}$ tube with $5 \mathrm{ml}$ of neurobasal medium. Spin at $300 \times \mathrm{g}$ for $5 \mathrm{~min}$ at RT. Remove supernatant and very gently resuspend the pellet in $1 \mathrm{ml}$ of NB medium and try breaking the clumps of cells very gently using a $1000 \mu$ pipette (pipet up and down maximum 3-4 times). Then leave the tube for 2-5 min to let the big clumps settle down at the bottom. Take the supernatant into another tube; thrash the pellet (the big clumps will not have mature cells but mainly proliferating precursor cells). 


\section{bïo-protocol

A

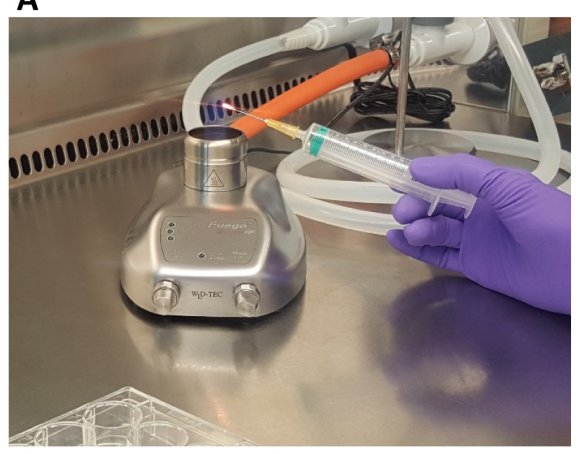

C

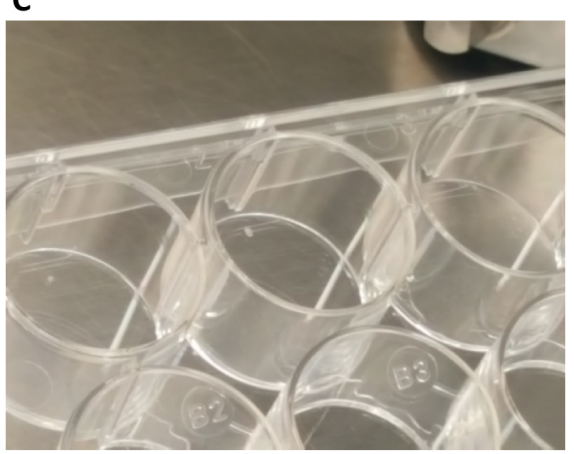

B

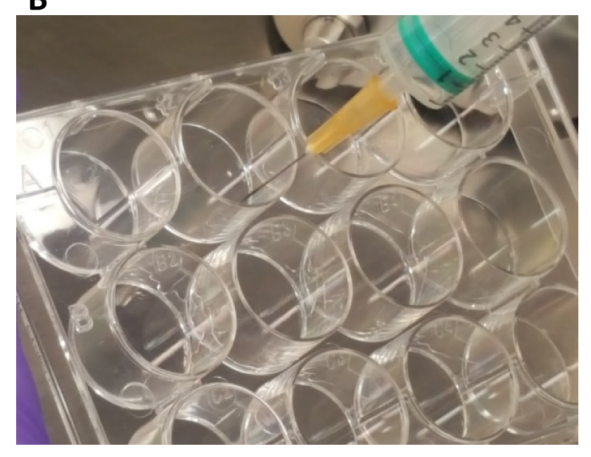

D

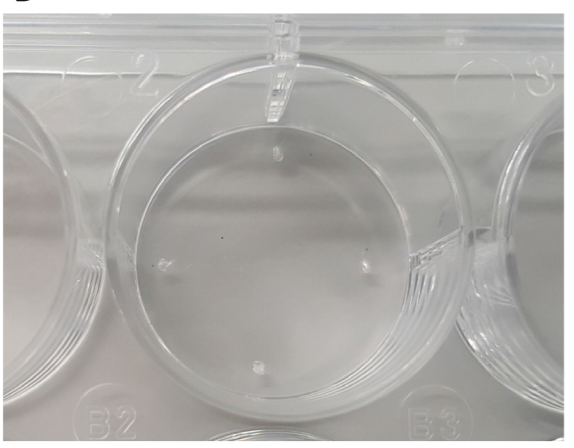

Figure 2. Sandwich plate preparation. A. Take a 12-well plate and a sterile syringe needle. Flame the needle until it is hot. With the hot needle, make a bump on 4 sides of the well (B-D). The astrocytes will be plated on the bottom of the plate, and a coverslip with neurons can be inverted on top. The coverslip will lean on the bumps. See also Video 1.

20. On Day 19, turn the coverslips with adhered neurons upside down over the bumps on the astrocyte plates.

Note: By now, the astrocytes should have reached $80 \%$ confluence in order to support the neurons.

21. Change half of the medium ( $500 \mu \mathrm{l} /$ well) twice a week with pre-warmed NB medium $+40 \mathrm{ng} / \mathrm{ml}$ $\mathrm{BDNF}+20 \mathrm{ng} / \mathrm{ml}$ GDNF $+20 \mathrm{ng} / \mathrm{ml} \mathrm{IGF1}+2 \mu \mathrm{M}$ cAMP.

22. On the day before the second refresh (Day 24/25), add $1 \mu \mathrm{M} \mathrm{AraC}$ to cultures to stop proliferation.

23. Next day (Day 25/26) refresh half of the medium (500 $\mu$ l/well) with pre-warmed NB medium + $40 \mathrm{ng} / \mathrm{ml} \mathrm{BDNF}+20 \mathrm{ng} / \mathrm{ml}$ GDNF $+20 \mathrm{ng} / \mathrm{ml} \mathrm{IGF} 1+2 \mu \mathrm{M}$ cAMP.

24. Keep cultures until Day 37 (see Figure 3), while refreshing medium twice a week as described in Step 21. 


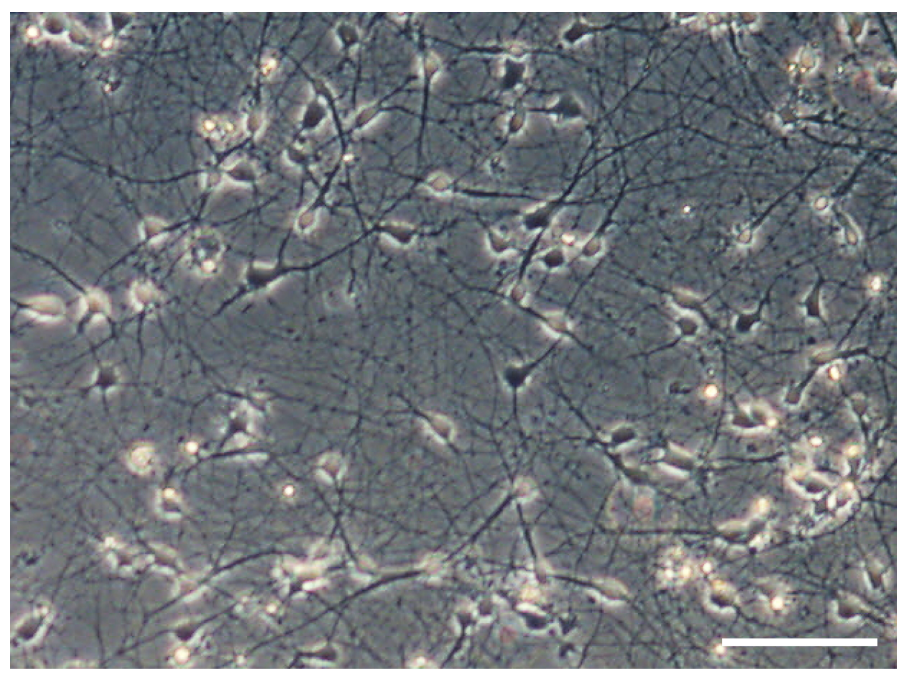

Figure 3. Brightfield picture of Day-37 neurons prior to co-culture showing neuronal network formation in sandwich culture. Scale bar $=100 \mu \mathrm{m}$.

B. OPC differentiation

OPCs are generated according to previously published protocol (Izrael et al., 2007), shortly:

1. hiPSCs are passaged with EDTA and plated on an anti-adherent 6-well plate in $3 \mathrm{ml}$ pre-warmed $\mathrm{NMM}$ with Vit A + $20 \mathrm{ng} / \mathrm{ml}$ EGF $+4 \mathrm{ng} / \mathrm{ml} \mathrm{bFGF}+10 \mu \mathrm{M} \mathrm{RI}+20 \mathrm{ng} / \mathrm{ml}$ T3 per well for embryoid body (EB) formation (see Figure 3).

Note: Use 2 wells of iPSCs for 1 well of EBs.

2. The next day (Day 1 ), refresh $2 / 3$ of the medium: swirl cells to the middle of the wells and carefully aspirate $2 \mathrm{ml}$ of medium. Add $2 \mathrm{ml}$ of pre-warmed NMM with Vit A $+20 \mathrm{ng} / \mathrm{ml} \mathrm{EGF}+4 \mathrm{ng} / \mathrm{ml}$ $\mathrm{bFGF}+10 \mu \mathrm{M} \mathrm{RI}+20 \mathrm{ng} / \mathrm{ml} \mathrm{T3}$.

3. On Day 2, refresh $2 / 3$ of the medium as described in Step B2 with pre-warmed NMM with Vit A+ $20 \mathrm{ng} / \mathrm{ml}$ EGF $+4 \mathrm{ng} / \mathrm{ml} \mathrm{bFGF}+10 \mu \mathrm{M} \mathrm{RA}$.

4. Repeat every other day.

5. On Day 10, plate EBs on Geltrex-coated plate as described in the note. If EBs become very dark, or decrease in density, plate EBs sooner than on Day 10, but not before Day 4. In our experience, Day 8 is mostly ideal (see Figure 4).

Note: Plate EBs on geltrex coated plate by collecting the medium with EBs in a 15 or $50 \mathrm{ml}$ tube. Leave the tube for 2-3 min to let the EBs settle. Carefully aspirate most of the medium, and resuspend EBs in the appropriate amount of desired medium (1 $\mathrm{ml}$ for a 12-well plate; $2 \mathrm{ml}$ for a 6-well plate). On Days 4-9, EBs are plated in pre-warmed NMM with Vit $A+20 \mathrm{ng} / \mathrm{ml} E G F+$ $4 \mathrm{ng} / \mathrm{ml} \mathrm{bFGF}+10 \mu \mathrm{M} R \mathrm{~A}+20 \mathrm{ng} / \mathrm{ml}$ T3. If EBs are plated on Day 10, NMM with Vit $A+20$ $n g / m l E G F+20 \mathrm{ng} / \mathrm{ml}$ T3 should be used instead. 


\section{bïo-protocol
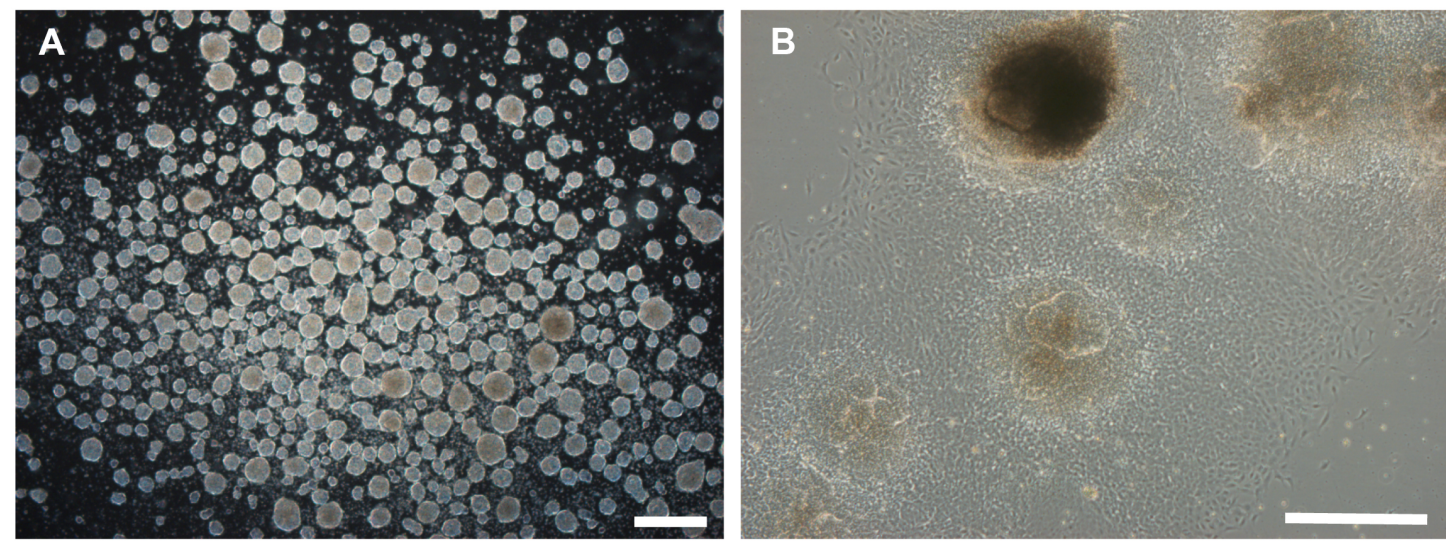

Figure 4. Brightfield pictures showing embryoid body formation (A) and outgrowth of cells from embryoid bodies after plating on a geltrex-coated plate (B). Scale bars $=500$ $\mu \mathrm{m}$.

6. On Day 10 , switch all medium to pre-warmed NMM with Vit A $+20 \mathrm{ng} / \mathrm{ml} \mathrm{EGF}+20 \mathrm{ng} / \mathrm{ml} \mathrm{T3}$.

7. From now on: refresh $2 / 3$ of the medium every other day and split cells when they reach $90 \%$ density to a new Geltrex-coated plate using accutase.

Note: Add RI to medium after passaging to help the cells recover.

8. On Day 18 , change medium to NMM without Vit $A+20 \mathrm{ng} / \mathrm{ml}$ EGF; keep refreshing and splitting cells as described in Step B7.

9. On Day 37 , change medium to NMM without Vit $A+5 \mathrm{ng} / \mathrm{ml} \mathrm{bFGF}+5 \mathrm{ng} / \mathrm{ml} \mathrm{EGF}+1 \mu \mathrm{g} / \mathrm{ml}$ mLaminin $+50 \mu \mathrm{g} / \mathrm{ml} \mathrm{Vit} \mathrm{C;} \mathrm{keep} \mathrm{refreshing} \mathrm{and} \mathrm{splitting} \mathrm{cells} \mathrm{as} \mathrm{described} \mathrm{in} \mathrm{Step} \mathrm{B7.}$

10. On Day 39 , change medium to NMM without Vit $A+5 \mathrm{ng} / \mathrm{ml} \mathrm{bFGF}+5 \mathrm{ng} / \mathrm{ml} \mathrm{EGF}+1 \mu \mathrm{g} / \mathrm{ml}$ $\mathrm{mLaminin}+50 \mu \mathrm{g} / \mathrm{ml} \mathrm{Vit} \mathrm{C}+50 \mathrm{ng} / \mathrm{ml}$ noggin; keep refreshing and splitting cells as described in Step B7.

11. On Day 42 , change medium to NMM without Vit $A+1 \mu \mathrm{g} / \mathrm{ml}$ mouse laminin $+50 \mu \mathrm{g} / \mathrm{ml} \mathrm{Vit} \mathrm{C}+$ $50 \mathrm{ng} / \mathrm{ml}$ noggin; keep refreshing and splitting cells as described in Step B7.

12. Keep OPC cultures in the medium of Step B11 until Day 65 (see Figure 5).
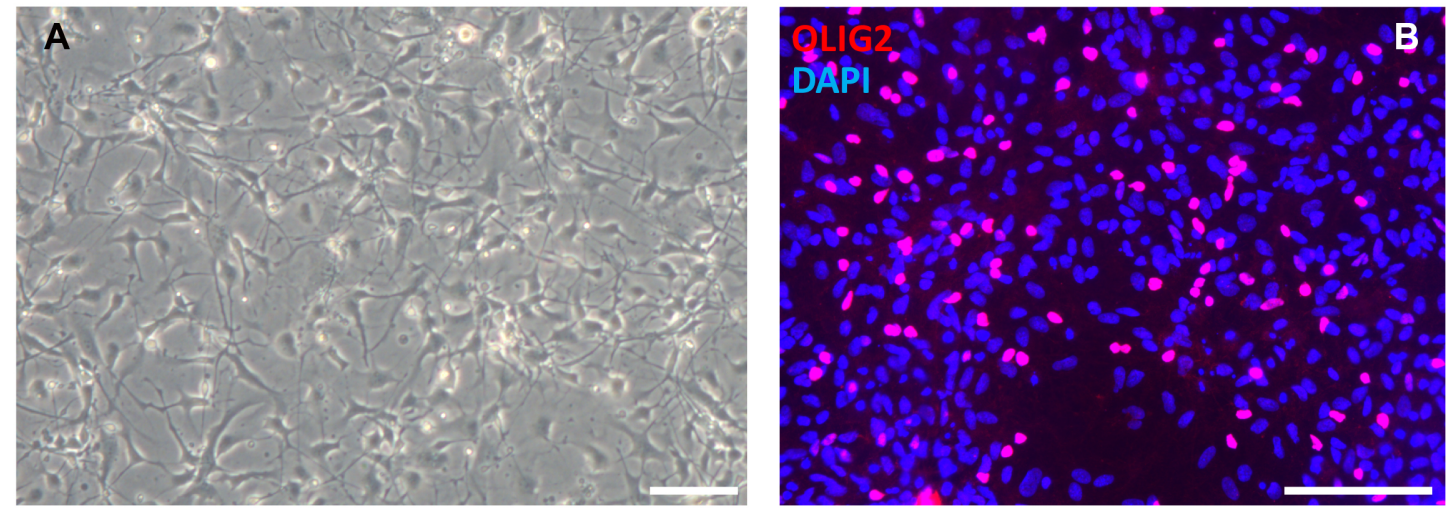

Figure 5. OPC differentiation. At the end of the OPC differentiation protocol, cells show a glial morphology (A, Day 45) and express OPC markers like OLIG2 (B, Day 65). Scale bars = 
$100 \mu \mathrm{m}$.

C. Neuron-OPC co-culture

1. At day 1 of co-culture, move the Day 37 neurons and plate Day 65 OPCs on top:

a. Take a new 12-well plate.

b. Pick the Day 37 neuronal coverslips up with a forceps from the rat astrocyte plate and plate in a new 12-well plate (with neurons on top, so flip coverslip compared to how it was on astrocyte plate).

Note: No coating is necessary for the new plate as the neuronal coverslips already contain the coating.

c. Add $1 \mathrm{ml}$ of pre-warmed neuroglia co-culture medium.

d. Get a plate with Day 65 OPCs.

e. Remove medium and wash plate once with PBS.

f. Remove PBS and add $750 \mu \mathrm{l}$ accutase to every well (6-well plate)

g. Incubate the plate for $5-10 \mathrm{~min}$ at $37^{\circ} \mathrm{C}$.

h. Check if cells are detaching from the plate by gentle tapping; if not, incubate longer.

i. When cells are detaching, collect cell suspension in a $15 \mathrm{ml}$ tube with $9 \mathrm{ml}$ pre-warmed DMEM/F12.

j. Spin down 5 min at $300 \times g$ at RT.

k. Resuspend cells in $1 \mathrm{ml}$ of pre-warmed neuroglia co-culture medium.

l. Remove $10 \mu \mathrm{l}$ of cell suspension for cell count.

m. Plate $4 \times 10^{5}$ OPCs per coverslip on a 12-well plate.

2. Refresh $1 / 2$ of the medium twice a week: remove $500 \mu$ l of medium and add $500 \mu \mathrm{l}$ of new prewarmed neuroglia co-culture medium.

3. At Day 28 of co-culture, fix cells with $4 \%$ PFA for $15-20$ min and use coverslips for immunostaining immediately (see Figure 6). 


\section{biö-protocol
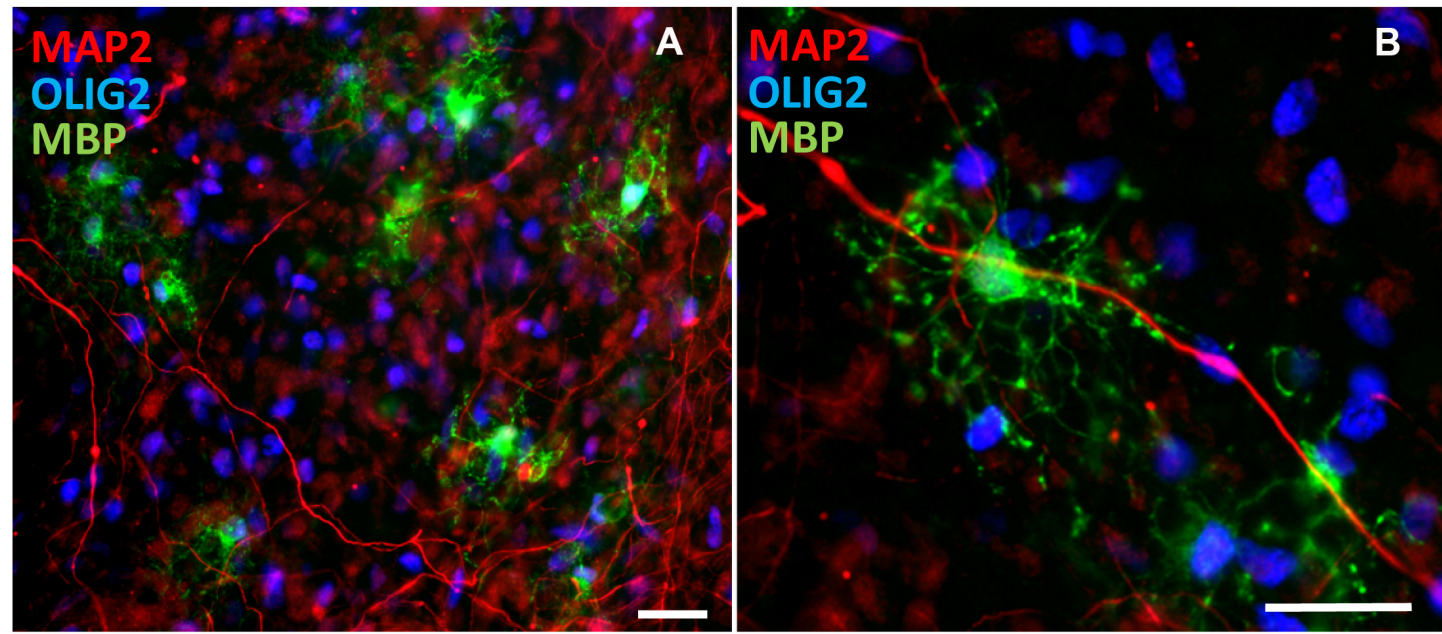

Figure 6. Immunostaining of co-cultures. (A) shows many OLIG2-positive OPCs and MBPpositive mature oligodendrocytes with MAP2-positive dendrites. (B) shows oligodendrocytes (MBP-positive) closely interacting with dendrites (MAP2-positive) Scale bars $=25 \mu \mathrm{m}$.

D. Immunostaining

1. Wash plate $6 \times 5$ min with PBS.

2. Remove PBS.

3. Add $300 \mu$ l blocking buffer per well.

4. Incubate for $1 \mathrm{~h}$ at RT.

5. Remove blocking buffer.

6. Add primary antibodies diluted in $300 \mu \mathrm{l}$ blocking buffer.

7. Incubate for $1 \mathrm{~h}$ at $\mathrm{RT}$, then overnight at $4{ }^{\circ} \mathrm{C}$.

8. Wash $6 \times 5$ min with PBS.

9. Add secondary antibodies diluted 1:1,000 in $300 \mu$ l blocking buffer.

10. Incubate for $2 \mathrm{~h}$ at RT.

11. Wash $6 \times 5$ min with PBS.

12. Remove PBS.

13. Add DAPI 1:1000 diluted in PBS.

14. Incubate for $2 \mathrm{~min}$ at RT.

15. Wash $1 \mathrm{x}$ with PBS.

16. Mount coverslips with Fluoromount $\mathrm{G}$ upside down on a microscopical slide.

\section{Data analysis}

1. Coverslips can be stained with markers for OPC maturation (for example OLIG2, MBP) and for markers of neuronal morphology (for example MAP2, SMI312). In our experience, for a control line there will be about $10 \% \mathrm{OLIG}^{+}$cells, $1-2 \% \mathrm{MBP}^{+}$cells and about $40 \%$ of the cells in the culture are $\mathrm{MAP}^{+}$neurons. 
Please cite this article as: Dooves et. al., (2019). Co-culture of Human Stem Cell Derived Neurons and Oligodendrocyte Progenitor Cells,Bio-protocol 9

Note: OLIG2 and MBP do not label all human oligodendrocyte lineage cells.

2. Cell properties can be analyzed by automated software packages, for example Columbus 2.5 online software (see https://www.perkinelmer.com/nl/product/image-data-storage-and-analysissystem-columbus for more information about the Columbus software and Figure 7 for example pictures of analysis) To analyze neuronal morphology, algorithms for morphology, soma recognition and co-localization can be used. More precisely, based on MAP2 and nuclear staining the dendritic density and average dendritic density per neuron can be determined. Similar analysis based on SMI312 staining can be used to analyze axonal density.

3. OPC maturation can be assessed using immunostaining for mature oligodendrocyte markers like MBP. Because different cell lines might grow at different speeds, and have different efficiencies in oligodendrocyte generation, it is best to correlate the number of MBP-positive to the number of OLIG2- positive OPCs.

4. The correct statistical analysis depends on the research question of interest. For example, this also depends on the culture set-up, i.e., when culturing 1 control oligodendrocyte line with neurons from different lines of patients and controls, vs. all combinations of control/patient oligodendrocytes with control/patient neurons. See Nadadhur et al. (2019) for how we performed statistical analysis.

A

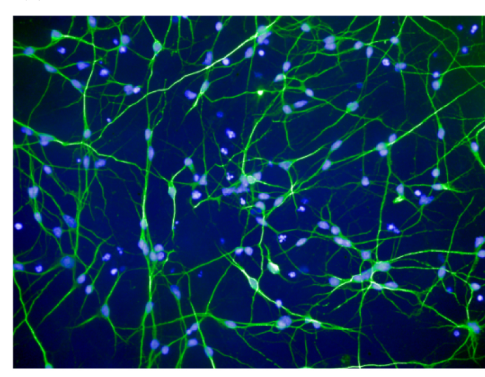

B

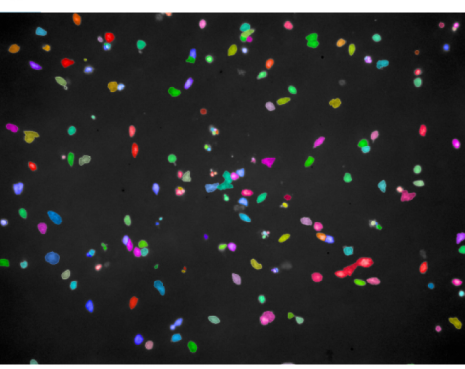

C

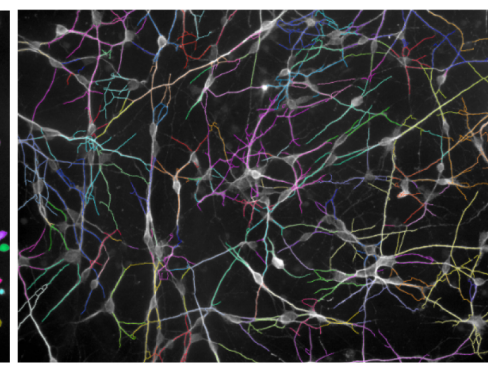

Figure 7. Example of cell analysis in Columbus. Fluorescent images can be imported into Columbus (A) which has preprogrammed settings to find nuclei $(B)$ and trace neurites $(C)$. The output includes parameters as the maximum neurite length, total neurite length and number of extremities per cell.

\section{$\underline{\text { Notes }}$}

As some variation is common in iPSC differentiation protocols, we recommend some quality checks before the start of a neuron-OPC co-culture.

1. Proper OPC differentiation can be verified by checking for OLIG2 expression around Days 5760 of the differentiation protocol.

2. Proper neuronal differentiation can be verified by staining for MAP2/beta-III tubulin/NeuN in the cultures on Day 37. If GFAP expression is observed, it is advised to discard cultures, as glia contamination could interfere with mixed co-cultures from patient and control iPSCs. See 
Nadadhur et al. (2017) for more glial free neuronal culture images.

\section{Recipes}

1. Neuroglia co-culture medium

$480 \mathrm{ml} \mathrm{DMEM} / \mathrm{F} 12$

$480 \mathrm{ml}$ Neurobasal

$10 \mathrm{ml} \mathrm{N} 1$ supplement

$20 \mathrm{ml} \mathrm{B27}$ supplement

$10 \mathrm{ml}$ NEAA

$60 \mathrm{ng} / \mathrm{ml} \mathrm{T3}$

$100 \mathrm{ng} / \mathrm{ml}$ Biotin

$10 \mathrm{ng} / \mathrm{ml} \mathrm{NT3}$

$1 \mu \mathrm{g} / \mathrm{ml} \mathrm{mLaminin}$

$20 \mathrm{ng} / \mathrm{ml}$ BDNF

$1 \mu \mathrm{M}$ cAMP

2. Neural Maintenance Medium (NMM) with Vitamin $A$

$482 \mathrm{ml} \mathrm{DMEM} / \mathrm{F} 12$ + glutamax

$482 \mathrm{ml}$ Neurobasal

$10 \mathrm{ml} \mathrm{B27}$ supplement with vitamin A

$5 \mu \mathrm{g} / \mathrm{ml}$ Insulin

5 ml Glutamax

$5 \mathrm{ml} \mathrm{N} 2$ supplement

$5 \mathrm{ml}$ NEAA

$10 \mathrm{ml}$ Pen/Strep

$10 \mu \mathrm{M} \beta$-mercaptoethanol

3. Neural Maintenance Medium (NMM) without Vitamin A

$482 \mathrm{ml} \mathrm{DMEM} / \mathrm{F} 12$ + glutamax

$482 \mathrm{ml}$ Neurobasal

$10 \mathrm{ml} \mathrm{B27}$ supplement without vitamin A

$5 \mu \mathrm{g} / \mathrm{ml}$ Insulin

$5 \mathrm{ml}$ Glutamax

$5 \mathrm{ml} \mathrm{N} 2$ supplement

$5 \mathrm{ml} \mathrm{NEAA}$

$10 \mathrm{ml}$ Pen/Strep

$10 \mu \mathrm{M} \beta$-mercaptoethanol

4. $\mathrm{N} 2$ medium

$48 \mathrm{ml} \mathrm{DMEM} / \mathrm{F} 12$ without L-glutamine

$500 \mu \mathrm{l} 100 \times \mathrm{N} 2$ 
$500 \mu \mathrm{l}$ Non-essential amino acids (10 mM stock)

$500 \mu \mathrm{l} \mathrm{L-glutamine} \mathrm{(200} \mathrm{mM} \mathrm{stock)}$

$2 \mu \mathrm{g} / \mathrm{ml}$ Heparin

$500 \mu \mathrm{l} \mathrm{Pen} /$ Strep

5. NB medium

$475 \mathrm{ml}$ Neurobasal

$10 \mathrm{ml} \mathrm{B27}$

18 mM HEPES

$1.25 \mathrm{ml}$ Glutamax

$5 \mathrm{ml} \mathrm{Pen/strep}$

6. Blocking Buffer

$95 \mathrm{ml}$ PBS

$5 \mathrm{ml} \mathrm{NGS}$

$300 \mu$ Triton $\mathrm{X}-100$

$0.1 \mathrm{~g} \mathrm{BSA}$

7. PBS

$8 \mathrm{~g} \mathrm{NaCl}$

$0.1 \mathrm{~g} \mathrm{KCl}$

$1.44 \mathrm{~g} \mathrm{Na}_{2} \mathrm{HPO}_{4}$

$0.24 \mathrm{~g} \mathrm{KH}_{2} \mathrm{PO}_{4}$

$800 \mathrm{ml} \mathrm{H}_{2} \mathrm{O}$

8. $\mathrm{PLO} / \mathrm{mLaminin}$ coating
a. Add to plate $20 \mu \mathrm{g} / \mathrm{ml}$ PLO in PBS $(0.5 \mathrm{ml}$ for 12 -well plate; $1 \mathrm{ml}$ for 6 -well plate)
b. Incubate at $37^{\circ} \mathrm{C}$ for $4 \mathrm{~h}$ or $\mathrm{O} / \mathrm{N}$
c. Remove PLO
d. Wash 3 times with PBS
e. Add to plate $20 \mu \mathrm{g} / \mathrm{ml} \mathrm{mLaminin}$ (same amounts as for PLO)
f. Incubate at $37^{\circ} \mathrm{C}$ for at least $2 \mathrm{~h}$ or $\mathrm{O} / \mathrm{N}$
g. Remove mLaminin
h. Add medium and cells

9. Geltrex coating
a. Dilute Geltrex 1:1 with cold DMEM/F12
b. Store aliquots at $-80^{\circ} \mathrm{C}$
C. Dilute 1:50 with cold DMEM/F12
d. Add to plate appropriate amount $(0.5 \mathrm{ml}$ for 12 -well plate; $1 \mathrm{ml}$ for 6 -well plate $)$
e. Incubate at $37^{\circ} \mathrm{C}$ for at least $1 \mathrm{~h}$
f. After remove Geltrex, immediately add medium with cells 


\section{Acknowledgments}

This study was financially supported by Amsterdam Neuroscience and EU MSCA-ITN CognitionNet (FP7-PEOPLE-2013-ITN 607508). V.M.H. is supported by ZonMw VIDI Research grant (91712343), E-Rare Joint Call project (9003037601) and a European Leukodystrophy Association (ELA) Research Grant (2014-012L1). Neuronal differentiation protocol is based on previous studies by Nadadhur et al. (2017). OPC differentiation protocol is based on the previous study of Izrael et al. (2007).

\section{Competing interests}

The authors declare no conflict of interest.

\section{Ethics}

All experiments were exempt from approval of Medical Ethical Toetsingscommissie (METC), Institutional Review Board of the VU medical center.

\section{References}

1. Almeida, R. and Lyons, D. (2016). Oligodendrocyte development in the absence of their target axons in vivo. PLoS One 11(10): e0164432.

2. Bergles, D. E., Roberts, J. D., Somogyi, P. and Jahr, C. E. (2000). Glutamatergic synapses on oligodendrocyte precursor cells in the hippocampus. Nature 405(6783): 187-191.

3. Clark, A. J., Kaller, M. S., Galino, J., Willison, H. J., Rinaldi, S. and Bennett, D. L. H. (2017). cultures with stem cell-derived human sensory neurons reveal regulators of peripheral myelination. Brain 140(4): 898-913.

4. Cui, Q. L., Fragoso, G., Miron, V. E., Darlington, P. J., Mushynski, W. E., Antel, J. and Almazan, G. (2010). Response of human oligodendrocyte progenitors to growth factors and axon signals. J Neuropathol Exp Neurol 69(9): 930-944.

5. Haroutunian, V., Katsel, P., Roussos, P., Davis, K. L., Altshuler, L. L. and Bartzokis, G. (2014). Myelination, oligodendrocytes, and serious mental illness. Glia 62(11): 1856-1877.

6. Hill, R. A., Medved, J., Patel, K. D. and Nishiyama, A. (2014). Organotypic slice cultures to study oligodendrocyte dynamics and myelination. J Vis Exp(90): e51835.

7. Izrael, M., Zhang, P., Kaufman, R., Shinder, V., Ella, R., Amit, M., Itskovitz-Eldor, J., Chebath, J. and Revel, M. (2007). Human oligodendrocytes derived from embryonic stem cells: Effect of noggin on phenotypic differentiation in vitro and on myelination in vivo. Mol Cell Neurosci 34(3): 310-323.

8. Kougioumtzidou, E., Shimizu, T., Hamilton, N. B., Tohyama, K., Sprengel, R., Monyer, H., 
Please cite this article as: Dooves et. al., (2019). Co-culture of Human Stem Cell Derived Neurons and Oligodendrocyte Progenitor Cells,Bio-protocol 9

Attwell, D. and Richardson, W. D. (2017). Signalling through AMPA receptors on oligodendrocyte precursors promotes myelination by enhancing oligodendrocyte survival. Elife 6: e28080.

9. Maldonado, P. P. and Angulo, M. C. (2015). Multiple modes of communication between neurons and oligodendrocyte precursor cells. Neuroscientist 21(3): 266-276.

10. Marques, S., Zeisel, A., Codeluppi, S., van Bruggen, D., Mendanha Falcao, A., Xiao, L., Li, H., Häring, M., Hochgerner, H., Romanov, R.A., Gyllborg, D., Munoz Manchado, A., La Manno, G., Lönnerberg, P., Floriddia, E.M., Rezayee, F., Ernfors, P., Arenas, E., Hjerling-Leffier, J., Harkany, T., Richardson, W.D., Linnarsson, S., Castelo-Branco, G. (2016). Oligodendrocyte heterogeneity in the mouse juvenile and adult central nervous system. Science 352 (6291): 1326-1329.

11. Nadadhur, A. G., Alsaqati, M., Gasparotto, L., Cornelissen-Steijger, P., van Hugte, E., Dooves, S., Harwood, A. J. and Heine, V. M. (2019). Neuron-glia interactions increase neuronal phenotypes in tuberous sclerosis complex patient iPSC-derived models. Stem Cell Reports 12(1): 42-56.

12. Nadadhur, A. G., Emperador Melero, J., Meijer, M., Schut, D., Jacobs, G., Li, K. W., Hjorth, J. J. J., Meredith, R. M., Toonen, R. F., Van Kesteren, R. E., Smit, A. B., Verhage, M. and Heine, V. M. (2017). Multi-level characterization of balanced inhibitory-excitatory cortical neuron network derived from human pluripotent stem cells. PLoS One 12(6): e0178533.

13. Pang, Y., Simpson, K., Miguel-Hidalgo, J. J. and Savich, R. (2018). Neuron/Oligodendrocyte myelination coculture. Methods Mol Biol 1791: 131-144.

14. Shi, Y., Kirwan, P., Smith, J., Robinson, H. P. and Livesey, F. J. (2012). Human cerebral cortex development from pluripotent stem cells to functional excitatory synapses. Nat Neurosci 15(3): 477-486, S471.

15. Treichel, A. J. and Hines, J. H. (2018). Development of an embryonic zebrafish oligodendrocyteneuron mixed coculture system. Zebrafish 15(6): 586-596.

16. van der Knaap, M. S. and Bugiani, M. (2017). Leukodystrophies: a proposed classification system based on pathological changes and pathogenetic mechanisms. Acta Neuropathol 134(3): 351-382.

17. Velez-Fort, M., Maldonado, P. P., Butt, A. M., Audinat, E. and Angulo, M. C. (2010). Postnatal switch from synaptic to extrasynaptic transmission between interneurons and NG2 cells. $J$ Neurosci 30(20): 6921-6929. 